\title{
Tussen letterlijkheid en vergeestelijking \\ Op zoek naar een passende interpretatie van de oudtestamentische heilsprofetie
}

\author{
A.J. van den Herik
}

\begin{abstract}
The prophets describe the future of Israel in a concrete manner and with vivid colours. Against the doom that Israel experiences, they proclaim a bright future, in which all that Israel received from the Lord, shall be restored. There is much discussion about how the interpretation of these eschatological pictures: more literally or more spiritually? Or is there a way in between? This article proposes an interpretative framework Starting with the basis and content of the prophetic hope (God's covenant) it explores the language and peculiarities of prophetic preaching, it shows how the context of the New Testament requires a recontextualization of the past promises, and it reaffirms the special position of Israel. The function of symbolism needs rearticulation.
\end{abstract}

\section{Inleiding}

Als de profeten de toekomst van Israël schilderen, doen ze dat op een zeer verheven, maar tegelijk concrete manier. We noemen uit de vele teksten enkele representatieve voorbeelden, die tegelijk de belangrijke thema's in de heilsverkondiging aansnijden. De stad Jeruzalem komt in een nieuw perspectief te staan. Ze zal rondom met edelstenen versierd zijn (Jes. 54:11-12) en baden in het licht van de heerlijkheid (kabôd) van JHWH (Jes. 60:2-3). De berg Sion, waarop de tempel gebouwd is, zal hoogverheven zijn en volken zullen overal vandaan, daarheen optrekken (Jes. 2:2-5 = Micha 4:1-4). Het huis van JHWH dat door de Babyloniërs verwoest werd, zal herbouwd worden en in ere hersteld en de offerdienst zal opnieuw functioneren (Jes. 56:7; Ez. 40-48; Zach. 3 en 4). Ook het land Israël zal rijk gezegend worden. De landbouwactiviteiten zullen elkaar in rap tempo opvolgen (Amos 9:13). Overal zal veiligheid en vruchtbaarheid zijn (Ez. 34:25-30). Alle stammen van Israël zullen weer in het Beloofde Land wonen; de vijandelijkheden tussen de noordelijke en zuidelijke stammen (Efraïm en Juda) zullen verdwijnen (Ez. 37:13-22; Jer. 31:1-25). Ze zullen in vrede leven onder een rechtvaardige Koning, die een 
nieuwe David zal zijn (o.a. Jes. 11:1-10; 32:1-18; Ez. 34:23-24; Jer. 23:5-6).

In de gegeven voorbeelden zien we dat het beloofde heil zich tot alle aspecten van Israël uitstrekt: de stad Jeruzalem, de tempel(dienst), het land, het volk (alle stammen) en de davidische koning. Alles zal in Gods heil delen. Vaak zijn deze beloften verbonden met de terugkeer uit de ballingschap. Tegenover de ellende die veroorzaakt werd door Gods toorn over hun zonden, staat het heil dat God over hen doet aanbreken. Het heil realiseert zich slechts door het oordeel heen. Dezelfde prediking blijft echter ook na de ballingschap klinken. Soms verkondigen de profeten dat er opnieuw een moeilijke tijd aan zal breken, met interne spanningen en verdrukking door de volken rondom. Pas daarna komt het beloofde heil (o.a. Jes. 66; Zach. 9-14; Dan. 7-12).

\section{Bijdrage aan de discussie}

De uitbundige toon van de heilsaankondigingen, verbonden met de concrete beschrijving ervan, heeft in de geschiedenis van de exegese nogal wat vragen opgeroepen. Hoe moeten wij deze heilsverkondiging lezen? In de kerkgeschiedenis is vaak gekozen voor een geestelijke uitleg. Met behulp van typologie en allegorie zochten veel kerkvaders naar de toepassing ervan voor de christelijke gemeente. In de gereformeerde traditie zag men deze concrete, materiële heilsbeloften vaak als een symbool van de geestelijke genade die God in het Nieuwe Testament aan de gemeente zou geven. Andere exegeten duidden dergelijke heilsbeloften echter bij voorkeur als toekomstig en betrokken ze op het heil dat God voor Israël zal bewerken, als het zich tot Jezus als Messias bekeert. ${ }^{1}$ Deze uitleg vinden we vooral in de puriteinse traditie, ${ }^{2}$ waarbij diverse Nederlandse

1 De puritein George Hutcheson zegt bij het genoemde Amos 9:13: 'Deze [...] Belofte kan Figuurlijk verstaan worden van veele Geestelijke Zegeningen, die onder deze Uitdrukkingen worden Aangewezen: doch het is veel klaarder om dezelve Letterlijk te verstaan, gelijk als Joël 3:18, van een grooten Uitwendigen Overvloedt, welke gelijk Hij die aan zijn Kerke somtijdts heeft besteedt, Hij ook op een bijzondere wijze daar een Blijk van geven zal aan het Bekeerde Israel.' Hoewel niet exclusief, betrekt Hutcheson deze tekst toch vooral op de tijd die aan zal breken als Israël Jezus als zijn Messias aanvaardt, cf. George Hutcheson, Zakelijke en praktikale verklaring van de twaalf kleine profeten. Reprint van Sakelyke en Prackticale Verklaringe van de twaalf kleine propheten 1, Leiden 1747, reprint: Utrecht 1980, 642. De kanttekeningen van de Statenvertaling duiden Amos 9:13 uitsluitend geestelijk. In de beloofde overvloed wordt 'de rijkdom en overvloed der geestelijke genade en zegeningen onder het Rijk van Christus (...) afgebeeld.'

2 De gedachte van een toekomstig aards vrederijk kwam ook in de vroege kerk voor. Daar werd ze echter meestal niet verbonden met het heil voor Israël. 


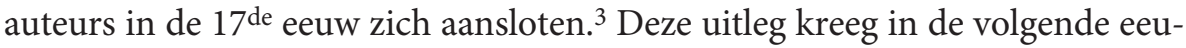
wen veel aanhang en werd vooral door de geschriften van J.N. Darby en C.I. Scofield populair. Vaak worden de heilsbeloften verbonden met de komst van het duizendjarig vrederijk (Openb. 20:4-6) en gezien als een beschrijving van het aardse heil dat Israël dan ten deel zal vallen. ${ }^{4}$

De discussie over een leeswijzer voor de profetische heilsverkondiging is in onze tijd volop actueel, met name door het verschijnen van de brochure Onopgeefbaar Verbonden ${ }^{5}$ (2011). De auteurs zien de oprichting van de staat Israël als een goddelijk ingrijpen. God is bezig zijn beloften aan Israël te vervullen. Ten onrechte is - volgens hen - de profetie in het verleden zonder meer gespiritualiseerd en geüniversaliseerd. Dit is echter in strijd met de eigenlijke bedoeling ervan. De kerk heeft niet de plaats van Israël ingenomen. De profetieën worden pas vervuld als Jezus concreet koning over Jeruzalem zal zijn en het Vrederijk aanbreekt. ${ }^{6}$ Dit zal in de (nabije?) toekomst gebeuren. De auteurs halen in de beschrijving van het toekomstige heil vooral profetieën van Zacharia aan. ${ }^{7}$ Deze opvatting heeft naast instemming ook veel tegenspraak opgeroepen. Sommigen hebben vooral bezwaar tegen haar letterlijke en exclusief op Israël gerichte lezing van de profetische heilsbeloften. S. Paas spreekt in dit verband van 'Israëlisme' en 'letterlijkheidswaan'. ${ }^{8}$ In dit artikel willen wij nader op deze kwestie ingaan. Wij stellen ons de vraag naar de betekenis van de realistische toekomstbeschrijving, zoals die binnen de profetische heilsprediking tot ons komt. Wat zijn de achtergrond, zeggingskracht en boodschap van deze realistische voorstellingen en wat betekent dat voor de interpretatie van deze teksten?

3 M. van Campen, Voetiaanse en coccejaanse visies op de joden gedurende de zeventiende en achttiende eeuw, Zoetermeer 2006.

4 Daarbij is er veel discussie over de vraag wanneer deze heilstijd precies aanvangt. In alle opvattingen vindt zij plaats voor Jezus' definitieve wederkomst om te oordelen over alle levenden en doden. Maar volgens het premillennialisme gaat daaraan een eerste wederkomst van Christus vooraf; het postmillennialisme ontkent dat. De premillennialistische opvatting is wereldwijd dominant.

5 M. van Campen, H.G. Abma en L. den Breejen, Onopgeefbaar verbonden, z.p. z.j (2011).

6 Er wordt niet uitdrukkelijk vermeld of men voor het pre- of postmillennialisme kiest. Gelet op de concreetheid waarmee Jezus' koningschap over Jeruzalem wordt getekend, lijkt men voor een premillennialistische opvatting te kiezen.

7 Zach. 1:17 (p. 6), Zach. 14 (in combinatie met Jesaja 60, p. 9), Zach. 12:2, 10; 14:3v, 16) (p. 19). Verwijzingen naar heilsverkondigingen uit andere profeten zijn schaars. Er wordt slechts nog verwezen naar Ez. 37 en Jer. 16:14v (p. 14).

8 S. Paas, Israëlvisies in beweging. Gevolgen voor Kerk, geloof en theologie (Kampen: Brevier 2014) 24. 


\section{Het verbond als de achtergrond van de oudtestamentische heilsver- wachting}

Om de oudtestamentische toekomstverwachting te begrijpen, moeten we haar allereerst plaatsen in het grotere kader waarin zij zich aan ons voordoet. Het kernwoord hierbij is belofte, aangevuld met het begrip vervulling. ${ }^{9}$ De basis daarvoor wordt gelegd in de Thora. God roept Abram op om op reis te gaan en zegt hem daarbij het land Israël toe als een eeuwig bezit ${ }^{10}$ voor hem en zijn nageslacht. ${ }^{11} \mathrm{Zij}$ zullen een groot volk worden. ${ }^{12}$ In Abram zullen alle geslachten van de aardbodem gezegend worden. ${ }^{13}$ De relatie tussen God en Abraham met zijn nageslacht krijgt het karakter van een verbond, waarvan de besnijdenis het teken is. ${ }^{14}$

De rest van de Pentateuch is een nadere ontvouwing en uitwerking van dit verbond. God roept Mozes als leider om het volk uit Egypte te verlossen en te brengen naar het land Kanaän. Hij is de God van Abraham, Izak en Jakob, maar maakt zich nu bekend met de naam JHWH. Israël is zijn eigen volk (Ex. 3:10). De herinnering aan die verlossing zal tijdens het Pascha levend gehouden worden. Israël ontvangt Gods wet en is geroepen om een koninkrijk van priesters en een heilig volk te zijn (Ex. 19:5-6). JHWH zelf komt bij hen wonen en geeft aanwijzingen onder welke voorwaarden zijn aanwezigheid gestalte moet krijgen. ${ }^{15}$ Israëls gehoorzaamheid is echter een kwetsbaar punt in de verbondsrelatie met JHWH. Leviticus 26 en Deuteronomium 28 benadrukken dat op gehoorzaamheid zegen volgt en op ongehoorzaamheid vloek. De heilsbeloften van Israël staan niet los van Genesis 1-11. Na het menselijk falen in de Hof van Eden, de zondvloed en de torenbouw van Babel, wordt

9 C. Rössel wijst erop dat het begrippenpaar 'belofte en vervulling' in het Oude Testament niet voorkomt. In plaats van het woord 'belofte' lezen we bijvoorbeeld: woord ('omer; 'imräh), of werkwoorden zoals: bevelen, spreken, zeggen, zweren etc. Zie Christoph Rössel, 'Verheißung/Erfüllung' Wibilex (2006). Geraadpleegd 18 maart 2020. Beschikbaar via http://www.bibelwissenschaft.de/stichwort/14477/.

10 Gen. 17:8.

11 O.a. Gen. $12: 7 ; 15: 7,18 ; 24: 7$.

12 O.a. Gen. 12:2; 17:20; 18:18; 46:3; 50:20; Deut. 26:5; 1 Kon. 3:8. Het aantal nakomelingen zal zijn 'als het zand van de zee', cf. Gen. 32:12; Jes. 10:22; Hos. 1:10, Rom. 9:27; Hebr. 11:12.

13 Gen. 12:1-3.

14 Gen. 15 en 17.

15 De regels voor de bouw van de tabernakel vinden we in het boek Exodus. De regels voor de eredienst vinden we voornamelijk in het boek Leviticus. 
Abraham verkoren en geroepen om een licht voor de volkeren te zijn. ${ }^{16}$

In de geschiedenis van Israël wordt meermalen duidelijk dat God zijn beloften nakomt. Jozua constateert dat '... er geen enkel woord van al de goede woorden die de HEERE, uw God, over u gesproken heeft, onvervuld gebleven is...' (Joz. 23:14). Deze vervulling is tegelijk de opmaat voor een nadere ontvouwing ervan. Het koningschap van David betekent de uitwerking van oude beloften. ${ }^{17}$ Op Gods bevel verkondigt Nathan David een eeuwige dynastie (2 Sam. 7). Voortaan zal David symbool staan voor de Messiaanse verwachtingen. De stad Jeruzalem, die door David tot hoofdstad gemaakt wordt en waar door Salomo de tempel zal worden gebouwd, krijgt theologische betekenis. Vanaf nu horen we niet alleen over een verkoren land en volk, maar ook over een verkoren dynastie en stad (in Deuteronomium was de plaats van het centrale heiligdom nog niet geïdentificeerd). De benaming Sion wordt de samenvatting van deze heilsverwachtingen. ${ }^{18}$

Als Salomo later terugkijkt op de regering van zijn vader, gebruikt ook hij het woord vervulling. 'Niet één woord is onvervuld gebleven van al Zijn goede woorden, die Hij gesproken heeft door de dienst van Mozes, Zijn dienaar' (1 Kon. 8:56). De heilstijd lijkt te zijn aangebroken (1 Kon. 4:25). Toch is dit niet de definitieve en volledige vervulling van Gods belofte. Integendeel, met Salomo's zonde begint de ontwrichting van het rijk, die zal uitlopen op de ballingschap.

Profeten geven geestelijk leiding aan het volk. Ze dreigen met Gods straf bij blijvende ongehoorzaamheid en roepen het volk tot inkeer. ${ }^{19}$ Ze wijzen terug naar Gods grote daden in het verleden, herinneren aan zijn beloften en werken die nader uit. De heilsverwachting is nauw met deze profetische reflectie

16 We kunnen spreken van een groeiend complex van heilservaringen en -beloften en de profetische reflectie erop, cf. bijvoorbeeld Claus Westermann, Hoofdlijnen van een theologie van het Oude Testament, Kampen 1991, 40-87; Walther Zimmerli, 'Verheißung und Erfüllung', Evangelische Theologie 12 (1952), 34-59; E. Noort, 'Toekomstverwachting in het Oude Testament - enkele aspecten', in: H. Baarlink e.a. (red.), Vervulling en voleinding. De toekomstverwachting in het Nieuwe Testament, Kampen 1984, 11-29.

17 In David komt Juda tot eer (Genesis 49: 8-12, Ruth 4: 16-22). In Davids macht wordt de belofte van heerschappij vervuld (Gen. 27: 29).

18 Ze trekt daarbij weer andere connotaties naar zich toe, zoals middelpunt van de schepping en grondsteen waarop de wereld is gebouwd (Jes. 28: 16). De bijzondere plaats van Jeruzalem als Sion wordt onderstreept door de bijzondere verlossing in 701 v.Chr., zie J. Dekker, De rotsvaste fundering van Sion. Een exegetisch onderzoek naar het Sionswoord van Jesaja 28, 16, Zoetermeer 2004.

19 Deut. 13: 1-3. 
verbonden. Voor dit werk zijn ze door God geroepen en ze krijgen van Hem kennis van zijn raad en plan (bijvoorbeeld Jer. 23:16-22 en Amos 3:7).

Ook in de Umwelt van het Oude Testament komen profeten voor. Extase en mantiek (droomduidingen etc.) waren vanouds middelen om de wil van de goden te ontdekken en vooral om zich van hun steun te vergewissen. Profeten speelden bij deze bemiddeling een belangrijke rol. De plaats die de profeet in Israël inneemt, verschilt daar wezenlijk van. Ook in Israël geven profeten antwoord op concrete vragen van mensen, ${ }^{20}$ maar hun eigenlijke boodschap gaat daar bovenuit. Gods doel is het laten aanbreken van een nieuwe tijd, waarin Hij de eigenlijke Koning van Israël en van de wereld is en zo ook erkend zal worden. We kunnen in dit verband spreken over de typisch eschatologische verwachting van de profeten. ${ }^{21}$ Eschatologie beschrijft hoe God zijn geschiedenis met Israël en de wereld tot een hoogte- en eindpunt brengt. ${ }^{22}$

Deze eschatologische verwachting wordt vooral actueel rond de ballingschap. Ondanks alle waarschuwingen van de profeten, keert het volk zich af van God en valt het doek voor Samaria (722) en Jeruzalem (586). Gods verbond schijnt op niets uitgelopen te zijn. Stad, tempel en land worden verwoest, de koning wordt afgezet en een behoorlijk deel van het volk verdwijnt naar Babel. De ballingschap wordt gezien als het oordeel van God over de zonden van het volk. JHWH laat echter Israël vanwege zijn verkiezing en verbond niet los. JHWH geeft het volk een nieuw toekomstperspectief. Deze nieuwe toekomst is uitsluitend te danken aan het ingrijpen van $\mathrm{JHWH}$, zoals ook reeds in de Thora was vermeld (Lev. 26:40-45; Deut. 30:1-10). De woorden van heil en verwachting die we bij de profeten vinden, zijn vaak al uitgesproken voor de ballingschap een feit was. Gods soevereiniteit biedt perspectief in deze crisis.

20 Zoals het terugvinden van weggelopen ezels, cf. 1 Sam. 9: 6.

21 Zie o.a. H.G.L. Peels, 'Eschatologie in het Oude Testament', in: W. van 't Spijker red., Eschatologie. Handboek voor de christelijke toekomstverwachting, Kampen 1999, 9-50, aldaar 10-13. Zie ook Eric Peels, "And It Shall Come to Pass in Those Days..." Eschatological Prophecy Between Literalizing and Spiritualizing', in: Hans Burger, Arnold Huijgen en Eric Peels (red.), Sola Scriptura: Biblical and Theological Perspectives on Scripture, Authority, and Hermeneutics. Studies in Reformed Theology dl. 32, Leiden, Boston 2018. Voor de buitenbijbelse profetie, cf. o.a. H.B. Huffmon, 'Prophecy: Ancient Near Eastern Prophecy', in: ABD 5, 477-482.

22 'It [= eschatology] is a study not of how the world ends or how time ends but rather of how the story ends - how God brings the biblical story to a climactic end', J.D. Hays, 'Prophecy and Eschatology In Christian Theology', in M.J. Boda en J.G. McConville (red.), Dictionary of the Old Testament: Prophets, Downers Grove 2012, 601. 


\section{Het verbond als de inhoud van de heilsverkondiging}

Niet alleen staat Gods belofte garant voor zijn blijvende betrokkenheid op Israël, zij bepaalt ook hoe de nieuwe toekomst eruit zal zien. ${ }^{23}$ Het land dat God vroeger aan Israël beloofde, zal hun opnieuw geschonken worden. Het koningschap zal hersteld worden; er komt een nieuwe David. De stad Jeruzalem zal herbouwd worden en de tempel en de eredienst hersteld. Het volk zal geestelijk vernieuwd worden. De nieuwe toekomst behelst het herstel van wat Israël in de verbondsrelatie met God geschonken is. Tegelijk is ze er ook de vernieuwing van. Het oude komt in een mooiere gestalte terug. Daarbij worden onvolkomenheden van vroeger gerepareerd. De toekomst zal in glans het heden overstijgen, maar bij alle discontinuïteit is de continuïteit doorslaggevend.

Deze vernieuwing heeft allereerst betrekking op het verbond zelf. Er komt een nieuw verbond (Jer. 31:31), waarbij JHWH het volk door zijn Geest innerlijk vernieuwt, zodat ze van hun zondige praktijken genezen worden en voortaan wel van harte God zullen dienen (Ez. 36:25-27; Jer. 31:27-34). Dit nieuwe verbond is een 'verbond van vrede' (Ez. 34:25-26) en een 'eeuwig verbond' (o.a. Jes. 55:3; 61:8; Jer. 32:40 en Ez. 37:26). Hoewel de toekomst geldt voor alle stammen van Israël, wordt ook vaak gesproken van een gelouterde rest die terugkeert. ${ }^{24}$

\section{Eigen perspectief en 'framing'}

Het valt op dat de details van de heilsprofetie bij de verschillende profeten nogal verschillen. We geven enkele voorbeelden. Jesaja 60 spreekt over de tempelstad Jeruzalem als stralend middelpunt. In Ezechiël 48:9-14 wordt echter een onderscheid gemaakt tussen de nieuwe stad en de nieuwe tempel; tussen beide ligt een behoorlijke ruimte. Weliswaar is bij Ezechiël de naam van de nieuwe stad 'JHWH is daar', maar ze is geen tempelstad meer en wordt ook geen Jeruzalem meer genoemd (48:35). Ook qua vorm lijkt de nieuwe stad niet op het eerdere Jeruzalem $(48: 15-20,30-35)$. De beschrijving in Zacharia 14:10 doet dat wel. In de tekening van het nieuwe land hoort het Overjordaanse bij Ezechiël er niet meer bij, maar in andere profetieën is dat wel het geval. ${ }^{25} \mathrm{Er}$ is ook een behoorlijk verschil in de taakomschrijving van

23 Ezechiël spreekt weinig expliciet over het verbond van God. De reden dat God zijn volk niet loslaat, is zijn zorg om de eer van zijn Naam, zijn reputatie als God van Israël (Ez. 36: 22, 32).

24 Deze aanduiding komt vaak voor in Jesaja, o.a. in 10: 19-22; 11: 11,16.

25 In Jer. 50: 19 en Zach. 10: 10 wordt Gilead bij Israël gerekend. In Obadja 19-20 staat ook dat Benjamin Gilead zal bezitten. 
de nieuwe vorst. Deze taak is in Ezechiël 45-46 (faciliteren en organiseren van de eredienst) veel minder verheven dan bijvoorbeeld in de beschrijving van Jesaja 11.

Deze voorbeelden maken duidelijk dat het in de profetische beschrijvingen - hoe concreet die ook zijn vormgegeven - niet gaat om een exacte beschrijving van wat komt. De afzonderlijke profetieën vormen geen aparte puzzelstukjes, die aan elkaar gelegd kunnen worden, zodat we een duidelijk beeld van de nieuwe toekomst krijgen. De afzonderlijke profetieën bieden elk een eigen perspectief en hebben hun eigen intentie. In de profetie correspondeert de beschrijving van de straf met de vloekwoorden die bij het verbond horen; de beschrijving van de zegen correspondeert met de bijbehorende zegeningen daarvan (Lev. 26 en Deut. 28). Deze achtergrond stempelt de beschrijving. ${ }^{26}$ In de heilsbeloften wordt ook teruggegrepen op eerdere ervaringen van Gods ingrijpen. ${ }^{27}$ Zo wordt de terugkeer uit de ballingschap beschreven in beelden, ontleend aan de exodus. Zoals toen, zal ook nu water droogvallen zodat Israël rivieren kan oversteken. Hitte en dorst zullen hen niet treffen. ${ }^{28}$ Walter Kaiser duidt deze toekomstbeschrijving aan als Back toward the Future. ${ }^{29}$

De toekomst wordt vanuit het verleden geduid en vormgegeven. Er is hierbij sprake van een zekere framing. ${ }^{30}$ Dit stijlmiddel onderstreept dat het in de profetie vooral om typering gaat en niet zozeer om een exacte beschrijving, maar het benadrukt ook dat de toekomst in Gods handen veilig is. De ervaringen met God in het verleden vormen een waarborg voor zijn handelen in de toekomst. Zoals God destijds reddend ingreep, zo zal Hij het ook in de toekomst doen.

26 Zie bijvoorbeeld de vele parallellen tussen Lev. 26 en Ez. 34, 37, cf. A.J. van den Herik, Een woonplaats voor de Heilige: onderzoek naar de strekking en relevantie van Ezechiël 40-48 vanuit een christelijk-theologische optiek. A Dwelling Place for the Holy One. A Study of the Intention and Relevance of Ezekiel 40-48 from a Christian Theological Perspective (With a Summary in English), Apeldoorn 2016, 230-231; R.L. Kohn, A New Heart and a New Soul. Ezekiel, the Exile and the Torah. JSOT, Londen 2002.

27 Evenzo wordt in de beschrijving van het oordeel teruggegrepen op eerdere oordelen van God. De vloek over Edom (Jes. 34: 9-10) roept bijvoorbeeld herinneringen op aan de straf over Sodom en Gomorra (Gen. 19).

28 Cf. Jes. 41:17vv. W. Zimmerli, 'Der "neue Exodus" in der Verkündigung der beiden grossen Exilspropheten', in: Gottes Offenbarung: gesammelte Aufsätze zum Alten Testament von Walther Zimmerli. Theologische Bücherei, Bd. 19, München 1963, 192-204.

29 W.C. Kaiser, Back toward the Future. Hints for interpreting Biblical Prophecy, Eugene 2003.

30 Framing (inkadering) betekent dat de werkelijkheid vooral vanuit een bepaalde hoek wordt bekeken. Door deze inkadering wordt een bepaalde zienswijze doorgegeven. 


\section{De actuele spits van de verkondiging}

De profetische verkondiging kenmerkt zich altijd door een persoonlijke en actuele spits. De gedachte dat profetie vooral voorzegging is, is wijdverbreid. Volgens die opvatting wordt over de hoofden van de toenmalige hoorders heen iets voorspeld, wat deze nauwelijks begrepen hebben en waarvan de betekenis pas veel later duidelijk zou worden. Nu onderstreept 1 Petrus 1: 10-13 weliswaar dat de diepte van een profetie pas later helemaal aan het licht kan komen, maar dit laat onverlet dat de profetische boodschap - als woord van troost of vermaning - ook door de eerste hoorders begrepen kon worden.

We kunnen profetie niet eenvoudigweg als voorzegging typeren. In de Engelstalige literatuur wordt in dit verband onderscheid gemaakt tussen foretelling en forthtelling. Foretelling kunnen we vertalen als voorzeggen: van tevoren aankondigen wat er gaat gebeuren. Bij een strikt letterlijke opvatting van de voorzegging, zou profetie gelijkstaan aan geschiedschrijving ante eventum. Voordat iets echt gebeurd is, weten we al exact hoe het gaan zal; het is immers voorzegd. Forthtelling kan vertaald worden als 'verder vertellen'. Profetie geeft - zo opgevat - de boodschap van God door en doet dat op een betrouwbare, duidelijke en gezaghebbende manier.

De actualiteit van de profetie blijkt uit haar aansluiting bij de contemporaine situatie. Een voorbeeld hiervan is Micha 5:1-8, waarin de geboorte van de Messiaanse Koning in Bethlehem beloofd wordt. Hij wordt beschreven als degene die het volk bevrijden zal van de dreiging van Assur. Voor de profeet en zijn tijdgenoten vormde Assyrië de grootste bedreiging. Voor latere hoorders krijgt 'Assyrië' een bredere strekking en staat deze concrete vijand symbool voor alle machten die Israël bedreigen. ${ }^{31}$

Profetie is vooral bedoeld om de hoorders wakker te schudden en te brengen tot gehoorzaamheid aan God. Hiermee krijgt zij iets voorwaardelijks, zoals blijkt uit Jeremia 18:5-12. Als zondige mensen zich van hun verkeerde weg afkeren, gaat de aangekondigde straf niet door. Als echter gehoorzame mensen zich van hun goede weg afkeren, gaat het aangekondigde heil niet door. Een klassiek voorbeeld van deze conditionele prediking (zonder dat de conditie genoemd wordt) is Jona's strafaankondiging tegen Ninevé. Door de bekering van Ninevé gaat het oordeel niet door. ${ }^{32}$ Profetie functioneert bin-

31 Ook Babel krijgt gaandeweg een soortgelijke symboolwaarde. Het wordt een voorbeeld van de God-vijandige wereld (Jer. 50).

32 Dat God op zijn anvankelijke dreigwoord terugkomt vanwege de reactie van de hoorder, zien we ook bij de genezing van Hizkia (2 Kon. 20:1-11, par. Jes. 38:1-8). In Jeremia 26:17-19 verwijzen de leiders van het volk naar de profetie van Micha (3:12). Deze kwam ook niet uit op de manier waarop Micha haar uitsprak. 
nen de context van de levendige communicatie tussen God en mens. God reageert op de menselijke reactie op zijn woorden. ${ }^{33}$ Een massieve opvatting van profetische verkondiging als onveranderlijke voorzegging doet onvoldoende recht aan het conditionele aspect van de profetische verkondiging. ${ }^{34}$ Door contingente reacties van hoorders kunnen profetieën soms niet vervuld worden. Soms worden ook profetieën anders vervuld of later dan oorspronkelijk gezegd werd. ${ }^{35}$ Dit doet echter niets af aan de betrouwbaarheid van het profetische woord. Als Woord (Weisung) van God is het volmaakt betrouwbaar. R.W. Klein vat dit mooi samen: God is faithfull and free. ${ }^{36}$ Hij is volstrekt betrouwbaar in zijn Woord - Hij meent wat Hij zegt; de intentie is duidelijk - maar hoe en wanneer zijn belofte of dreiging precies gestalte krijgt, is zijn zaak.

\section{Symboliek, tijd en perspectief}

Hierboven noemden we de symbolische meerwaarde die concrete namen als 'Assur' kunnen krijgen. Een dergelijke symbolische meerwaarde komen we ook tegen in andere concrete beschrijvingen. Een voorbeeld hiervan is de nieuwe tempel zoals Ezechiël die beschrijft. In het Oude Nabije Oosten werden tempels beschouwd als een kleine weergave (microkosmos) van het universum (macrokosmos). ${ }^{37}$ De tempel was een afspiegeling van de hemel. Op allerlei manieren herinnerde de tempel ook aan het paradijs en de Hof van Eden (in vroegjoodse geschriften wel de eerste tempel genoemd). ${ }^{38}$ Dit betekent dat in de belofte van een nieuwe tempel een veelheid van verwachtingen

33 Zie ook Ezechiël 18:21-29.

34 Een intrigerend voorbeeld is de profetie van Ezechiël tegen Tyrus (Ez. 26:7-11). Aan Nebukadnessar wordt de overwinning op Tyrus toegezegd. Daarin faalt hij echter. Dit feit wordt erkend in de profetie tegen Egypte (Ez. 29:17-21). In plaats daarvan wordt hem nu een andere opdracht gegeven. Uiteindelijk geschiedt de verwoesting van Tyrus (waarvan Jes. 23 en Ez. 29 profeteren) pas in 332 door Alexander de Grote.

35 R. Chisholm, 'When Prophecy Appears to Fail, Check your Hermeneutic', JETS 53 2010, 561-577.

36 R.W. Klein, 'Yahweh Faithful and Free: Ezekiel's Response to Exile', in: R.W. Klein red., Israel in Exile. A Theological Interpretation. OBT, Philadelphia 1979.

37 Zie o.a. J.H. Walton, Ancient Near Eastern Thought and the Old Testament. Introducing the Conceptual World of the Hebrew Bible, Grand Rapids 2006) 113-134; G.K. Beale, The Temple and the Church's Mission. A Biblical Theology of the Dwelling Place of God, Downers Grove 2004.

38 Cf. G.J. Brooke, 'The Ten Temples in the Dead Sea Scrolls', in: Temple and Worship in Israel 417-434, aldaar 419-421. 
en voorstellingen meekwam die voor ons pas na vergelijkend onderzoek vanuit de context van het Oude Nabije Oosten zichtbaar wordt. Kennis van de conceptuele wereld van het Oude Oosten is nodig om de precieze impact van deze beschrijvingen te duiden. Wie zich fixeert op de letterlijke beschrijving, mist de symbolische meerwaarde en uiteindelijk ook de bedoeling ervan.

Eén van de opvallendste - en verwarrendste - aspecten in de profetische heilsverkondiging is het gebrek aan temporele differentiatie. Het lijkt erop dat voor de profeten de terugkeer uit de ballingschap het begin is van de eschatologische heilstijd. Dit blijkt echter niet het geval te zijn. We moeten ons hierbij realiseren dat de profeten bewust ongedifferentieerd over de toekomst hebben gesproken. De vaak gebruikte tijdsaanduidingen als 'in het laatste der dagen', 'het einde', 'te dien dage', 'de dagen komen ...' of 'te dien tijde' zijn nogal onbepaald.

Hoewel soms enige temporele differentiatie niet ontbreekt, wordt de toekomst vooral als één geheel beschreven. Dit fenomeen wordt vaak betiteld als 'profetisch perspectief' of 'telescoped history'. ${ }^{39}$ Het beeld dat hierbij vaak gebruikt wordt, is dat van een berglandschap. Wie naar de toppen van een berglandschap kijkt, kan denken dat deze dicht bij elkaar liggen. Hij ziet echter niet dat zich daartussen diepe en brede dalen bevinden. Wat in één keer beschreven wordt, kan temporeel ver uit elkaar liggen. Een voorbeeld hiervan is Zacharia 9:9-10. Het Nieuwe Testament interpreteert Jezus' feestelijke intocht in Jeruzalem als een vervulling van vers 9 (Matth. 26: 28; Luk. 22: 20). In het volgende vers is echter sprake van de eschatologische vrede die deze Koning brengt: vernietiging van alle oorlogsmaterieel, universele vrede en heerschappij over de volken. Dit ligt ook voor ons nog in de toekomst. Beide aspecten worden echter in de teksten heel nauw verbonden.

Dit profetische perspectief heeft een betekenis. Het maakt duidelijk dat voor de profeten alles wat gebeuren zal, uiteindelijk een eenheid vormt. God is bezig heen te werken naar zijn eindtriomf. Het ontbrekende tijdsperspectief maakt de profetische verkondiging tegelijk actueel. De profeten benadrukken steeds dat JHWH's ingrijpen direct aanstaande is. Zijn toekomst is onweerstaanbaar onderweg. Dit geeft aan de toekomstbeschrijving een actuele, persoonlijke spits. In haar dreiging en vertroosting roept zij ook nu op tot

39 M.J. Paul, 'Profetisch licht bij Jesaja', in: J. Hoek red., Profetisch licht. Toekomst voor Israël en de kerk. Theologische Hogeschool van de Gereformeerde Bond "Johannes Calvijn" (THGB) 6, Heerenveen 2013, 20-47. 
volharding en waakzaamheid. ${ }^{40}$ Jezus' spreken over de wederkomst (bijvoorbeeld in Mattheüs 24) heeft dezelfde structuur en bedoeling. ${ }^{41}$

\section{Israël als hermeneutische sleutel?}

In het voorgaande hebben we gezien dat de heilsprofetie in zekere zin haar eigen 'grammatica' en 'vocabulaire' heeft. Zij beschrijft de toekomst op haar eigen, typerende manier en gebruikt daarbij haar eigen beelden en voorstellingen. Dit betekent - zo zagen we - dat de profetie ons niet zomaar een beschrijving en routekaart geeft van de toekomst. Tegelijk zagen we dat de dragende grond van de profetie het verbond van God is. Dat verbond bepaalt ook haar inhoud.

De kwestie waarvoor de theologie zich geplaatst weet, is de vraag hoe we deze oude beloften lezen binnen een christelijk-theologische context. In de discussie waaraan we in het begin refereerden, wordt de vraag gesteld naar de blijvende betekenis van Israël. Moet Israël niet fungeren als een hermeneutische sleutel? Gaan alle profetieën uiteindelijk niet over wat Israël in de toekomst overkomt? Een veronderstelling daarbij is dat veel profetieën gedeeltelijk of helemaal nog niet vervuld zijn.

We gaan - uiteraard heel beknopt - eerst in op de vraag naar de blijvende betekenis van Israël. Wat betreft de rol van het verbond en de plaats van Israël kunnen we - kort gezegd - in het Nieuwe Testament twee hoofdlijnen ontdekken. Enerzijds wordt in het Nieuwe Testament de universaliteit van Gods heil sterk benadrukt. Heidenen horen voluit bij het ene volk van God (Ef. 2:11-22). In 2 Korinthe 6:16 benadrukt Paulus dat de christelijke gemeente de tempel van God is. Dit onderstreept hij door de verbondsformule te gebruiken, waarbij woorden uit Leviticus 26:12 en Ezechiël 37:27 samengevoegd zijn. In 1 Petrus 2:9 worden kwalificaties van Israël uit Exodus 19:5 toegepast op de gemeente: 'een koninklijk priesterschap, een heilig volk, een volk dat God Zich ten eigendom maakte.' De kern van de beloften van het nieuwe verbond (Jer. 31) gelden ook de gemeente (Hebr. 10:15-17).

Aan de andere kant houdt Israël wel een bijzondere plaats. De komst van Christus is tot heerlijkheid van het volk van Israël (Luk. 2:25) In Romeinen

40 J. de Vuyst, 'Enkele hermeneutische opmerkingen over apokalyptische stoffen', in: J. van Genderen red., Ten dienste van het Woord (Fs. W.H. Velema), Kampen 1991, 196-202, aldaar 198-199.

41 In deze eschatologische rede wordt de verwoesting van Jeruzalem en de wederkomst in één perspectief gezien. De geografische gezichtskring van waaruit alles bezien wordt is Judea (Mt. 24:15-22). Zie hierover H. Ridderbos, De komst van het Koninkrijk. Jezus' prediking volgens de synoptische evangeliën, Kampen 1985, 3e druk, 444-447. 
9-11 wordt gesproken over Gods blijvende betrokkenheid op het concrete Israël. ${ }^{42} \mathrm{Op}$ grond daarvan acht ik het onjuist om de bijzondere positie van Israël te ontkennen. Tegelijk hebben ook heidenen een legitieme plaats in Gods koninkrijk ontvangen; ze delen door Christus in de aan Israël geschonken verwachting. Dit betekent dat bij het nadenken over heilsbeloften Israël wel een unieke, maar geen exclusieve plaats inneemt.

\section{De actuele betekenis van het verbond met Israël}

Als het verbond van God met Israël echter nog steeds actueel is, hoe zit het dan met de inhoud van de belofte: volk, land, stad, tempel en koningschap? Deze vormen immers de inhoud van de heilsbelofte. Net als in het Oude Testament, wordt ook in het Nieuwe Testament het belang van deze thema's onderstreept. Als Zoon van David is Jezus de Koning van Israël (Luk. 1: 32-33). Jeruzalem is de 'heilige stad' (o.a. Matth. 27: 53). Zij heeft toekomst, ook al zal ze verwoest worden (Luk. 21: 24). Ook na de uitstorting van de Heilige Geest bezoeken de apostelen de tempel (Hand. 3: 1). Het evangelie is allereerst voor de Joden bestemd (Hand. 3: 25-26). Daarom krijgen de apostelen de opdracht met hun prediking te beginnen in Jeruzalem, Judea en Samaria (Hand. 1: 8).

Tegelijk zien we een perspectiefwisseling. Niet slechts het land Israël is van belang, maar ook de wereld. ${ }^{43}$ Christus is de vervulling van de tempel en de eredienst. Hij is niet alleen de Koning van Israël, maar ook van de wereld en zijn nieuwe volk bestaat ook uit heidenen. Dit betekent echter niet dat de band met Israël wordt doorgesneden. Deze band blijft zelfs na de wederkomst bestaan. Er komen een nieuwe aarde en een nieuwe hemel met daarin een nieuwe stad, die opnieuw de naam Jeruzalem draagt met poorten waarop de namen van de twaalf stammen van Israël staan (Openb. 21). Deze stad is voor Israël én de heidenen. Groter eer voor Jeruzalem is niet denkbaar.

Mijns inziens betekent dit voor de christelijke theologie, dat ze denkend vanuit Gods verbond, gesloten met Israël, niet om de blijvende betekenis van

42 Het lijkt me onjuist 'Israël' in Romeinen 9-11 anders te interpreteren dan als het concrete, historische Israël. Van een wisseling in betekenis (van een letterlijk naar een meer geestelijk Israël) is in deze hoofdstukken geen sprake.

43 Voor de betekenis van het land in het Nieuwe Testament, zie Boris Paschke, 'The Land in the New Testament', in: H. Koorevaar en M.J. Paul red., The Earth and the Land: Studies about the Value of the Land of Israel in the Old Testament and Afterwards. EDIS, Edition Israelogie dl. 11, New York 2018, 277-304. Volgens Paschke wordt het land in het Nieuwe Testament vaak vergeestelijkt, maar gebeurt dat zeker niet altijd. Het land Israël blijft ook in zijn concrete geografische gestalte theologisch voor ons van belang. 
Israël heen kan. Maar daarnaast heeft ook de kerk haar legitieme plaats. Het verbond met Israël is niet vervangen door een verbond met de kerk, maar het is - zoals we hierboven zagen - wel uitgebreid en omvat nu ook de gemeente. Als volk van Gods verbond houdt Isräl echter haar unieke betekenis. Gods belofte behelst ook de gave van het land. Het is legitiem om de terugkeer van het volk naar Israël en Jeruzalem na eeuwenlange ballingschap vanuit dit perspectief te bezien. Tegelijk zien we dat de noties van tempel en koningschap met Christus' koningschap en priesterschap een andere invulling hebben gekregen. ${ }^{44}$

\section{Recontextualisering en symboliek}

We kunnen het bovenstaande nog iets nader concretiseren. Om recht te doen aan de plaats van Israël en aan de literaire eigenheid van de profetische tekst, moeten we twee belangrijke uitgangspunten in het oog houden: recontextualisering en symboliek.

\section{Recontextualisering}

Onder recontextualisering verstaan we de actualisering van oude teksten in een nieuwe context. Daarbij is belangrijk hoe de oude betekenis in de nieuwe context meeklinkt. De betrokkenheid op de context is met de profetische prediking zelf gegeven. Als communicatie van Godswege spreekt het mensen in voor hen verstaanbare taal aan. Profetische woorden zijn steeds ingebed in de geschiedenis die God met zijn volk gaat. Dit betekent ook dat ze in nieuwe contexten steeds weer geactualiseerd kunnen worden. De kern van de belofte verandert niet, maar de concrete verwoording en toepassing ervan kunnen wel wijzigen. ${ }^{45}$

We zien deze recontextualisering onder andere in de manier waarop in het Nieuwe Testament oudtestamentische heilsbeloften worden geactualiseerd. Vanuit het nieuwe perspectief van Jezus' overwinning worden oude beloften opnieuw gelezen. De beschrijving van het Nieuwe Jeruzalem in Openbaring 21 laat dat zien. We horen toespelingen op en echo's van oude profetieën. ${ }^{46}$

44 We mogen Gods beloften aan Israël niet 'vervluchtigen', maar evenmin 'verharden', aldus terecht G. van den Brink en C. van der Kooi, Christelijke dogmatiek. Een inleiding, Zoetermeer 2012, 343.

45 G.K. Beale gebruikt hierbij het voorbeeld van een vader die in 1900 aan zijn zoon een buggy (koetsje) belooft als deze gaat trouwen. Als de zoon trouwt, zijn buggies echter verouderd, omdat de auto zijn intrede heeft gedaan. Daarom krijgt de zoon nu een auto. Naar de letter houdt de vader zijn belofte niet, maar naar de geest wel; hij geeft immers een passend vervoersmiddel en dat is de kern, Beale, Temple and the Church's Mission, 291.

46 Zie voor een indruk van de teksten waarop toespelingen plaatsvinden de Griekse tekst NA28. 
Het beeld dat van de nieuwe stad gegeven wordt, is anders dan van elk van de oudtestamentische profetieën afzonderlijk en ook meer dan een samenvatting ervan, maar in de kern is het ermee congeniaal. De oude en de nieuwe beelden verkondigen ieder op eigen weergaloze wijze dat God in Zijn genade bij mensen wonen wil. In Christus is dat nu nog mooier dan eerst gezegd kon worden.

De manier waarop de Schrift haar woorden zelf recontextualiseert, geeft ons een hermeneutische bril om de profetie te lezen. Ze is geen exacte beschrijving van wat komt, maar biedt in verstaanbare woorden en voorstellingen een lokkend perspectief en opent zo een venster op de nieuwe toekomst. Nieuwe perspectieven voegen zich hierin bij de oude. Zo beschouwd is hier sprake van een sensus plenior: een diepere betekenis dan de eigenlijke auteur bevroedde, maar die niet in tegenspraak met zijn woorden is. ${ }^{47}$

Wie de profetieën leest, hoeft geen letterknecht te zijn van de woorden, maar is wel gebonden aan haar kernboodschap: de eschatologische verwachting dat God zijn rijk doet komen voor Israël en de volken en zich daarbij trouw betoont aan zijn verbond met Israël. Hoe die toekomst er precies uitziet, is aan Hem. En bij Hem is het in goede handen.

\section{Symboliek}

In de discussie over de uitleg van profetie wordt nogal eens een scherp onderscheid gemaakt tussen een geestelijke en een letterlijke uitleg. In het bovenstaande hebben we gezien dat profetische taal meermalen symbolisch is. Symbooltaal biedt hermeneutische mogelijkheden. De taal van de mythe en het symbool doorbreken volgens Ricoeur het rationeel-descriptieve betoog en maken een dimensie van de werkelijkheid zichtbaar die op andere manieren onzichtbaar blijft. ${ }^{48}$

De toekomstbeelden die de heilsprofetieën oproepen hebben ook deze functie. In hun concreetheid geven ze inhoud aan verwachtingen die niet in

47 Cf. 1 Petr. 1:10-13. Zie hierover breder: K.J. Vanhoozer, Is There a Meaning in this Text? The Bible, the Reader, and the Morality of Literary Knowledge, Grand Rapids 1998, 314. Deze opvatting van een 'bredere betekenis' lijkt op de gedachte dat profetieën 'gelaagd' zijn. Er kunnen na een eerste vervulling nog meerdere lagen van vervullingen komen, meer geestelijk of letterlijk, op Israël of de kerk gericht, cf. Paul, 'Profetisch licht bij Jesaja'. Deze laatste opvatting kan iets sjabloonmatigs krijgen: naast een letterlijk vervulling, is er ook nog een geestelijke of op Israël gerichte vervulling. De gedachte van recontextualisering doet mijns inziens meer recht aan het dynamische en verrassende van de belofte. Net als bij een diamant valt er steeds nieuw licht op de diverse facetten. De oude belofte kan op een heel onverwachte manier weer gaan spreken.

48 P. Ricoeur en J.A. Meijers, Symbolen van het kwaad [vertaling uit het Frans], Rotterdam 1970. 
abstracte begrippen te vatten zijn. Ze beschrijven niet, maar suggereren en typeren. Ze roepen iets op, dat zo niet op een andere manier uitgedrukt zou kunnen worden. Daarbij raken ze niet alleen het intellect, maar ook het gevoel en de wil. Ze zetten ons aan om ons denken en handelen door deze toekomst te laten bepalen. De aardse beelden waarin de verwachting wordt uitgedrukt, laten daarbij zien dat Gods heil concreet gestalte krijgt. De symboliek heeft zo een verkondigende functie.

Het is echter wel van belang dat we de symbolen lezen binnen hun eigen verstaanskader. Wie als christelijke exegeet zonder meer bijbelse profetieën invult vanuit zijn eigen christelijke context en niet eerst zorgvuldig naar de eigen woorden en concepten van de tekst en zijn context luistert, loopt het gevaar om de oudtestamentische woorden tekort te doen en er vreemd aan te blijven. Pas wanneer we aan het eigen geluid van de tekst recht doen, is er ruimte om deze stem naast de andere bijbelse stemmen te laten klinken en een plaats te geven in het bredere verband van de christelijke canon.

Calvijn maakt in zijn hermeneutiek een onderscheid tussen de vraag wat de heilsbeloften voor de contemporaine hoorders betekenden en wat zij voor de christelijke gemeente van nu betekenen. ${ }^{49}$ De betekenis die de tekst voor de christelijke gemeente heeft, houdt ook verband met de heilshistorische positie die wij innemen. Het is belangrijk deze twee stappen te onderscheiden en expliciet te maken. ${ }^{50}$

\section{Conclusie}

De heilsprofetieën schilderen een rijke toekomst. Israël neemt in deze beloften een bijzondere positie in. Wie deze profetieën slechts letterlijk opvat, mist de clou. Wie ze vergeestelijkt, dreigt ze tot een tijdloze waarheid te maken. De nieuwe toekomst wordt beschreven op een eigen manier en in beelden en symbolen die verwachtingen oproepen. Deze gebruikte symbolen spreken hun eigen taal. Kennis van de conceptuele wereld van het Oude Nabije Oosten is daarbij onmisbaar. Het Oude Testament mag en moet daarbij voor zichzelf

49 Zie o.a. W. de Greef, Calvijn en het Oude Testament, Amsterdam 1984, 209-236.

50 Het ontkennen van deze dubbele beweging heeft in de geschiedenis veel kwaad gedaan. In discussie tussen christenen en joden is aan de joden vaak 'domheid' verweten. Ze zouden grof en zinnelijk zijn als ze de geestelijke (lees: christelijke) interpretatie niet volgden. Helaas maakt ook Calvijn zich daar meerdere malen schuldig aan. De tegenstelling letterlijk-geestelijk is ongeschikt om het verschil tussen de joodse en christelijke uitleg te typeren. Ook de Joodse exegese is niet altijd letterlijk. Maimonides las de profetie van het vredige dierenrijk symbolisch als een belofte dat er onder mensen geen oorlog meer zal zijn (Hilchot Melachim, c. 12. sect. 1). 
spreken. Tegelijk echter lezen we deze teksten mede vanuit het perspectief dat het Nieuwe Testament ons biedt. Zo gaan symbolen spreken en getuigen ze van de betrouwbaarheid van God. Zo worden symbolen tot cymbalen en bezingen ze Gods trouw en grootheid. ${ }^{51}$

A.J. van den Herik is predikant van de hervormde gemeente binnen de PKN van Dordrecht (wijk 2) en deeltijds gastdocent aan de ETF in Leuven.

51 Gerrit Achterberg en R.L.K. Fokkema, Symbolen worden tot cymbalen. Een bloemlezing uit zijn gedichten. Bert Bakker bloemlezing, Amsterdam 1991, 112. 